\title{
Penambahan Tepung Rimpang Temulawak (Curcuma xanthorriza Roxb) dan Tepung Rimpang Temu Putih (Curcuma zedoaria Rosc) dalam Ransum Komersial Terhadap persentase Karkas, Lemak Abdomen, Dan Persentase Hati Pada Ayam Pedaging.
}

\author{
Yustin Golla*), M. E. R Montong**), Jacqueline T. Laihad**) dan \\ Godlief D.G Rembet**) \\ Jurusan Produksi Ternak, Fakultas Peternakan Universitas Sam Ratulangi, Manado \\ Jl. Kampus Unsrat, Bahu Manado 95115
}

\begin{abstract}
This research aims to determine the extent which the effectiveness of the addition of turmeric powder (Curcuma Roxb xhantorriza) and a ginger and white (Curcuma zedoria Rosc) in commercial rations on carcass percentage, amdominal fat, and the percentage ol liver in bloiler. The material used is old broiler 3 weeks as much as 53 tails. The design used was a completely randomized design with 6 treatments 3 replications. The treatmens were applied as follows: $\mathrm{R}_{0}=$ basic ration without ginger, and ginger and white, $R_{1}=$ base $+2 \%$ ration ginger rhizome flour, $R_{2}$ $=$ base $+2 \%$ ration rhizome ginger and white flour. The result sho wed that the edition of flour and ginger rhizome of ginger and white flour in the ration was not significantly different $(p>0,05)$ on carcass percentage, abdominal fat, liver percentage. It can be concluded that the addition of ginger rhizome flour and white flour as much as $2 \%$ in the commercial ration still give the same response to the carcass percentage, abdominal, and the percentage of liver.
\end{abstract}

Keywords :_Broiler Chicken, Ginger Rhizome Flour, Ginger And White

*) Alumni Fakultas Peternakan Unsrat

**) Jurusan Produksi Ternak Fakultas Peternakan Unsrat 


\begin{abstract}
ABSTRAK
Penelitian ini bertujuan untuk mengetahui sejauh mana efektifitas penambahan tepung rimpang Temulawak (Curcuma xhantorriza roxb) dan Temu Putih (Curcuma zedoria rosc) dalam ransum komersial terhadap persentase karkas, lemak abdomen, dan persentase hati pada ayam pedaging. Materi yang digunakan adalah ayam pedaging umur 3 minggu sebanyak 54 ekor. Rancangan yang digunakan adalah rancangan acak lengkap dengan 3 perlakuan 6 ulangan. Perlakuan yang diterapkan sebagai berikut : $\mathrm{R}_{0}=$ ransum dasar tanpa temulawak, dan temu putih, $\mathrm{R}_{1}=$ ransum dasar $+2 \%$ tepung rimpang temulawak, $\mathrm{R}_{2}=$ ransum dasar $+2 \%$ tepung rimpang temu putih. Hasil penelitian menunjukan bahwa penambahan tepung rimpang temulawak dan tepung rimpang temu putih dalam ransum tidak memberikan pengaruh yang berbeda nyata $(\mathrm{P}>0,05)$ terhadap persentase karkas, lemak abdomen, persentase hati. Dapat disimpulkan penambahan tepung rimpang temulawak dan tepung rimpang temu putih sebanyak $2 \%$ dalam ransum komersial masih memberikan respon yang sama terhadap persentase karkas, lemak abdomen, dan persentase hati ayam pedaging.
\end{abstract}

Kata Kunci : Ayam Pedaging, Temulawak, Temu Putih

\title{
PENDAHULUAN
}

Peternakan ayam pedaging di Indonesia merupakan salah satu usaha yang cukup besar menempati posisi teratas pada unggas yang ketersediaanya cukup banyak. Usaha peternakan ayam pedaging merupakan usaha yang paling cepat dan efesien dalam memenuhi kebutuhan daging bagi masyarakat. Ayam pedaging memiliki performance yang sangat baik dengan karakteristik khusus seperti pertumbuhan cepat, memiliki daging yang tebal, serta masa pemeliharaan yang relatif singkat ( Tamalludin, 2012). Dewasa ini konsumsi akan daging ayam semakin meningkat. Hal ini karena harganya relatif murah dibandingkan dengan harga daging ayam kampung. Hal yang tidak disukai oleh konsumen karena kadar lemak pada ayam broiler cukup tinggi.

Dilihat dari fenomena yang ada maka diperlukan alternatif lain untuk menurunkan kadar lemak pada karkas ayam pedaging. Salah satu alternatif yang digunakan untuk dapat menurunkan kadar lemak dalam karkas ayam yaitu menggunakan ramuan herbal. Feed additive atau pakan tambahan adalah suatu bahan yang ditambahkan pada pakan atau ransum dalam jumlah terntentu dan dengan tujuan tertentu

Dari sekian banyak tanaman yang digunakan, temulawak (Curcumae zanthorriza) dan temu putih (Curcumazedoria roxb) merupakan pakan tambahan 
(feed aditive) yang digunakan dalam ransum. Feed aditive dimaksudkan untuk memacu pertumbuhan dan meningkatkan efisiensi pakan dengan mengurangi mikroorganisme pengganggu atau meningkatkan populasi mikroba yang menguntungkan, yang ada dalam saluran pencernaan ayam sehingga efisiensi penggunaan pakan akan meningkat.(Suprijatna 2005)

(Sufiriyanto dan Indradji, .2007) Menyatakan Temulawak merupakan tanaman herbal yang termasuk ke dalam antibiotik alami dan tidak mengakibatkan residu atau berbahaya apabila dikonsumsi oleh ternak atau manusia. Temulawak (Curcuma xanthorrhiza) juga mengandung zat aktif "xanthorizol" yang dapat menghambat pertumbuhan jamur dalam tubuh. Selanjutnya menurut Widodo (2002) bahwa penggunaan rimpang temulawak optimalnya $2 \%$ dalam ransum masih dapat meningkatkan bobot badan ayam. Penggunaanya tidak boleh melebihi karena adanya karena adanya kandungan minyak atsiri. Hal disebabkan karena minyak atsiri mempunyai rasa yang tajam dan bau yang khas sehingga bila digunakan dalam ransum unggas harus dibatasi. Afifah (2003)

Temu putih (Curcumae zedoria Roxb) berkhasiat memperkuat pencernaan, manambah selera makan, merangsang gerakan usus dan menghilangkan perut kembung (Salim, 1995). Temu putih mengandung minyak atsiri dan komponen kurkuminoid yang berfungsi membantu pencernaan merangsang sistim saraf sehingga keluar getah lambung yang mengandung enzim seperti pepsin, tripsin, trypsin, lipase, amylase, disekresikan kedalam lambung dan usus sehingga diharapkan dapat meningkatkan metabolisme zat makanan (Guenther, 1997). Namun penggunaanya harus dibatasi karena adanya efek minyak atsiri terhadap fungsi atau kerja saluran pencernaan khususnya usus halus dan bersifat racun pada dosis yang berlebihan, maka penggunaan temu putih yang tepat diharapkan mampu meningkatkan metabolisme tubuh yang dapat mempengaruhi sel-sel saluran pencernaan. Oleh karena itu penelitian ini dilaksanakan untuk mempelajari efek dari penambahanan temulawak dan temu putih dalam ransum terhadap persentase karkas, lemak abdomen, dan persentase hati ayam pedaging.

\section{MATERI DAN METODE PENELITIAN}

Ternak yang digunakan dalam penelitian ini ayam broiler berumur 3 minggu sebanyak 53 ekor yang terbagi menjadi 3 perlakuan 6 ulangan, pada masing-masing ulangan terdiri dari 3 ekor. Perlakuan yang diberikan $\mathrm{R}_{0}$ : Ransum dasar tanpa temulawak, dan temu putih, $\mathrm{R}_{1}$ : ransum dasar $+2 \%$ tepung rimpang temulawak dan $\mathrm{R}_{2}$ : ransum dasar $+2 \%$ tepung rimpang temu putih. Rancangan yang digunakan pada penelitian ini adalah Rancangan Acak Lengkap (RAL). Penelitian ini dilakukan dikandang percobaan Jurusan ilmu Produksi Fakultas Peternakan Universitas Sam Ratulangi Manado.

\section{Variabel yang diamati}


Variabel yang diukur dalam penelitian ini adalah persentase karkas, lemak abdomen, dan persentase hati ayam broiler.

1. Persentase karkas

2. Persentase lemak abdomen

3. Persentase hati

\section{Analisa Data}

Penelitian ini dilasanakan menggunakan randomized completely design dan data hasil penelitian di analisis menggunaka analisis of variance Rancangan Acak Lengkap (RAL) (Steel dan Torrie, 1994).

\section{HASIL DAN PEMBAHASAN}

\subsection{Pengaruh Perlakuan Terhadap Persentase Karkas}

Data hasil perhitungan rataan persentase karkas dari masing-masing perlakuan yang diberikan selama penelitian tercantum pada Tabel 3.

\begin{tabular}{cccc}
\hline Ulangan & $\mathbf{R 0}$ & $\mathbf{R 1}$ & $\mathbf{R 2}$ \\
\hline 1 & 75,65 & 74,43 & 75,26 \\
2 & 75,55 & 75,01 & 74,37 \\
3 & 75,62 & 73,83 & 75,74 \\
4 & 77,12 & 73,10 & 71,92 \\
5 & 76,02 & 72,02 & 75,58 \\
6 & 73,40 & 74,82 & 74,50 \\
\hline Total & 453,35 & 443,21 & 447,37 \\
\hline Rataan & 73,56 & 73,87 & 74,56 \\
\hline
\end{tabular}

Rataan persentase karkas untuk masing-masing perlakuan berkisar (Tabel 4) antara 73,56\% - 74,56\%. Hasil penelitian ini masih pada kisaran yang direkomendasikan oleh North (1990) bahwa persentase karkas menurut metode pemotongan "Ready too cook" yang paling baik berkisar antara $70 \%-77 \%$.

Hasil analisis ragam (lampiran 1a) menunjukan bahwa perlakuan yang digunakan tidak memberikan pengaruh yang nyata $(\mathrm{P}>0.05)$ terhadap persentase karkas. Hal ini menunjukan bahwa setiap perlakuan memberikan respon yang sama terhadap persentase karkas. Ini disebabkan oleh kandungan zat-zat makanan dalam ransum percobaan tidak jauh berbeda (Tabel 3). 
Tidak berbedanya persentase karkas ini diduga disebabkan oleh jumlah konsumsi ransum (lampiran 4) dan pertambahan bobot badan (lampiran 5) hampir sama untuk setiap perlakuan. Robbins, (1981) bahwa faktor-faktor yang yang menentukan persentase karkas antara lain adalah : berat badan, umur ternak, perlemakan dan isi saluran pencernaan.

Dari data yang tercantum pada (Tabel 4) menunjukan bahwa perlakuan yang menggunakan $2 \%$ rimpang temulawak menghasilkan persentase karkas lebih tinggi diikuti dengan perlakuan yang menggunakan $2 \%$ temu putih sebagai penambahan dalam ransum, dibandingkan yang diberikan ransum control (komersial). Widodo (2002) menyatakan salah satu fungsi dari rimpang temulawak dan temu putih adalah untuk menambah nafsu maka sehingga mempengaruhi konsumsi ransum (lampiran 4) berakibat pada pertambahan berat badan (lampiran 5). Selanjutnya (Wijayakusuma, 2003) menyatakan bahwa minyak atsiri yang terkandung pada temulawak dan temu putih dapat mempercepat pengosongan lambung dengan demikian akan timbul rasa lapar dan merangsang nafsu makan. Pada akhirnya akan berpengaruh terhadap pertambahan berat badan dan akan berpengaruh terhadap persentase karkas.

Pengaruh perlakuan yang tidak berbeda nyata terhadap persentase karkas pada penelitian ini menggambarkan bahwa penambahan $2 \%$ temulawak dan temu putih dalam ransum ayam pedaging tidak menyebabkan penurunan persentase karkas, dalam arti kandungan zat-zat makanan yang ditambahkan dalam ransum control $\left(\mathrm{R}_{0}\right)$ mencukupi kebutuhan ayam pedaging dan tidak mempengaruhi keseimbangan zat-zat makanan dalam ransum, sehingga persentase karkas dapat tercapai. Menurut Anggorodi, H. R. (1994 : 8), persentase karkas ayam dapat dipengaruhi oleh jenis strain, umur, jenis kelamin, berat hidup dan makanan. Persentase karkas ayam jantan lebih besar dibandingkan persentase karkas ayam betina, karena karkas pada ayam betina lebih banyak menghasilkan kulit dan lemak abdomen daripada ayam jantan.

\subsection{Pengaruh Ransum Perlakuan Terhadap Persentase lemak abdomen}

Hasil pengamatan rataan lemak abdomen dari masing-masing perlakuan yang diberikan selama penelitian tercantum pada Tabel 4.

\begin{tabular}{cccc}
\hline Ulangan & $\mathbf{R 0}$ & $\mathbf{R 1}$ & $\mathbf{R 2}$ \\
\hline 1 & 1,45 & 1,25 & 1,15 \\
2 & 1,69 & 1,61 & 2,07 \\
3 & 1,10 & 1,92 & 1,99 \\
4 & 2,93 & 1,06 & 1,42 \\
5 & 1,46 & 1,42 & 1,71 \\
6 & 1,77 & 1,06 & 1,75 \\
\hline Total & 10,41 & 8,31 & 10,09 \\
\hline Rataan & 1,73 & 1,38 & 1,68 \\
\hline
\end{tabular}


Rataan persentase lemak abdomen pada penelitian ini berkisar antara $1.38 \%$ $1.73 \%$ dari bobot badan. Hasil penelitian ini masih dalam kisaran yang dikemukakan oleh Maffudz (2009) bahwa rataan persentase lemak abdomen berkisar antara 0.73$3.78 \%$ masih dalam kisaran yang normal untuk ayam broiler, apabila lebih besar dari nilai tersebut maka kualitas karkas sudah menurun. North (1990) menyatakan bahwa lemak abdomen merupakan indikator lemak karkas. Hal ini disebabkan karena ketika lemak abdomen meningkat maka berdampak pada kualitas karkas.

Untuk mengetahui secara jelas bagaimana pengaruh penambahan temulawak dan temu putih pada level yang sama yaitu $2 \%$ dibandingkan dengan ransum control (komersial) terhadap persentase lemak abdomen maka dilakukan analisis sidik ragam pada lampiran 2 tersebut terlihat bahwa pengaruh penambahan temulawak dan temu putih, pada level yang sama $2 \%$ dibandingkan dengan ransum control (komersial) tidak memberikan pengaruh yang nyata $(\mathrm{P}>0,05)$ terhadap persentase lemak abdomen. Artinya penambahan rimpang temulawak dan temu putih masih memberikan respon yang sama terhadap persentase lemak abdomen.

Walaupun secara statistik tidak berbeda nyata namun rataan persentase lemak abdomen pada (Tabel 5) mneunjukan perlakuan yang menggunakan $2 \%$ temulawak $\left(\mathrm{R}_{1}\right)$ dan temu putih $\left(\mathrm{R}_{2}\right)$ lebih rendah di bandingkan dengan $\left(\mathrm{R}_{0}\right)$ ransum control (komersial).

Rendahnya persentase lemak abdomen pada $\left(\mathrm{R}_{1}\right)$ dan $\left(\mathrm{R}_{2}\right)$ karena adanya kandungan minyak atsiri yang berfungsi merangsang produksi empedu dan sekresi pankreas serta mempunyai kemampuan sebagai bakterisida, (Darwis SN. 1991). Selanjutnya menurut (Wijayakusuma, 2003) bahwa minyak atsiri dan kurkumin mempunyai khasiat merangsang sel hati untuk meningkatkan produksi dan memperlancar sekresi cairan empedu yang berfungsi mengemulsi lemak. Hal ini akan mengurangi partikel-partikel padat yang terdapat dalam kantung empedu dan mengakibatkan kandungan lemak menurun.

\subsection{Pengaruh Perlakuan Terhadap Persentase Hati}

Rataan persentase hati masing-masing perlakuan tercantum pada Tabel 5.

\begin{tabular}{cccc}
\hline Ulangan & R0 & R1 & R2 \\
\hline 1 & 1,78 & 1,30 & 1,70 \\
2 & 1,43 & 1,69 & 1,56 \\
3 & 1,91 & 1,99 & 1,50 \\
4 & 1,67 & 1,78 & 1,68 \\
5 & 1,61 & 1,67 & 1,71 \\
6 & 1,70 & 1,98 & 1,00 \\
\hline Total & 10,10 & 10,40 & 9,16 \\
\hline Rataan & 1,68 & 1,73 & 1,53 \\
\hline
\end{tabular}


Rataan persentase hati hasil penelitian untuk masing-masing perlakuan berkisar antara 1.68-1.73\% dari berat hidup. Carwell (1980) menyatakan bahwa persentase hati untuk ayam pedaging umur 6 minggu berkisar antara $1.73-2.3 \%$ dari berat hidup.

Untuk mengetahui secara jelas sejauh mana pengaruh penambahan temulawak dan temu putih pada level yang sama yaitu $2 \%$ dibandingkan dengan ransum kontrol (komersial) terhadap persentase hati maka dilakukan analisa statistik yang hasilnya tercantum pada lampiran 3. Berdasarkan analisis ragam pada lampiran tersebut terlihat bahwa pengaruh penambahan temulawak dan temu putih pada level yang sama yaitu $2 \%$ dibandingkan ransum control (komersial) tidak memberikan pengaruh yang nyata $(\mathrm{P}>0,05)$ terhadap persentase hati ayam pedaging. Artinya penambahn $2 \%$ rimpang temulawak dan temu putih dalam ransum kontrol (komersial) belum memberikan perbedaan pada persentase hati, karena masih dalam kisaran yang sama dengan persentase hati ayam pedaging yang diberikan ransum kontrol (komersial) tanpa rimpang temulawak dan temu putih.

Walaupun secara statistik tidak berbeda nyata namun rataan persentase hati pada (Tabel 6) mneunjukan perlakuan yang menggunakan $2 \%$ rimpang temu putih $\left(\mathrm{R}_{2}\right)$ lebih rendah diikuti dengan yang menggunakan ransum control $\left(\mathrm{R}_{0}\right)$ dibandingkan dengan yang menggunakan temulawak $\left(\mathrm{R}_{1}\right)$. Whittow (2002) menyatakan bahwa berat hati dipengaruhi oleh beberapa faktor seperti jenis hewan, besar tubuh, genetik serta pakan yang diberikan. Selanjutnya North (1987) menyatakan bahwa berat hati dipengaruhi oleh bangsa, umur, dan kandungan nutrisi dalam ransum.

Menurut (Blakely and Bade, 1991) Fungsi fisiologis hati yaitu sekresi empedu untuk mengemulusi lemak, penetralisir racun, tempat penyimpanan energi yang siap untuk dipakai seperti glikogen serta menguraikan hasil sisa protein menjadi asam urat untuk dikeluarkan oleh ginjal. Senyawa beracun akan mengalami proses detoksifikasi seluruhnya. Hal inilah yang dapat mengakibatkan hiperthrophi hati.

\section{KESIMPULAN}

Berdasarkan hasil analisis data dan pembahasan dari hasil penelitian dapat disimpulkan bahwa penambahan temulawak dan temu putih dengan dosis $2 \%$ dalam ransum komersial masih memberikan respon yang sama terhadap persentase karkas, lemak abdomen, dan persentase hati ayam pedaging yang baik.

\section{DAFTAR PUSTAKA}

Alfifah, E. dan Tim Lentera, 2003.Khasiat dan Manfaat Temulawak. PT Gramedia Pustaka, Jakarta. 
Blakely, J and D. H. Bade. 1991. Ilmu Peternakan. Diterjemahkan oleh Srigandono, Bambang. UGM Press: Yogyakarta.

Crawley, S. W., D. R. Sloan and R. K. Hale. 1980. Yield and composition of edible and inedible by-product of broiler processed at 6,7 and 8 week of age. Poultry Sci. 59: 2244-2246

Darwis SN. (1991). Tumbuhan Obat Famili Zingiberaceae : Puslitbang Tanaman Industri. Bogor.

Guentar. E. 1997. Minyak Atsiri. Diterjemahkan oleh S.Ketaren. Universitas Indonesia Jakarta

Kubena, L.F., J.W. Deaton, T.C. Chen and F.N. Reece. 1974. Factors Influencing the quality

Mahfudz, 2009.Karkas dan Lemak Abdominal Ayam Broiler yang Diberi Ampas Bir dalam Ransum. //http://aPNR3-(28)_Lutfi-2-seting.pdf//.[TanggalAkses : 14Maret 2011].

North, M. O. and D. D. Bell. 1990. Commercial Chicken Product Manual. 4 Th Ed Reinhold New York

Robbins, K. R. 1981. Effect of sex, breed, dietary energy level, energy soure and calorie : Protein ration performance and energy utilization by broiler chicks. Poult. Sci. $60: 2306-2315$

Sufiriyanto dan Indradji M. 2007.Efektivitas Pemberian Ekstrak Temulawak (Curcumaexanthoriza) danKunyit (Curcumaedomestica) dan Sebagai Immunostimulator Flu Burung pada Ayam Niaga Pedaging. J. Animal Production $9: 178-183$.

Suprijatna, E., U. Atmomarsono, R. Kartasujana. 2005. Ilmu Dasar Ternak Unggas. Penebar Swadaya. Jakarta.

Steel R.G. D and J.H. Torrie. 1991. Prinsip dan Proesedur Statistik ( Suatu Pengantar Biometrik ) Terjemahan B. Sumantri. PT. Gramedia. Jakarta.

Tamalludin , F . 2012. Ayam Broiler, 22 Hari Panen Lebih Untung. Penebar Swadaya. Jakarta 2012.

Widodo, W. 2002. Nutrisi dan Pakan Unggas Kontekstual. Proyek Peningkatan Penelitian Pendidikan Tinggi Direktorat Jendral Pendidikan Tinggi Departemen Pendidikan Nasional. Jakarta

Wijayakusuma, H., 2003. Penyembuhan dengan Temulawak. Milenia Populer. Jakarta. 
Whittow, G., 2002. Strukies Avian Phsycology. $5^{\text {th }}$. Academic Press. USA. 